\title{
Assessing foraging strategies of herbivores in Mediterranean oak woodlands: a review of key issues and selected methodologies
}

\author{
Maria Isabel Ferraz de Oliveira • Elsa Lamy • Miguel N. Bugalho • \\ Margarida $\mathrm{Vaz} \cdot$ Cristina Pinheiro - Manuel Cancela d'Abreu • \\ Fernando Capela e Silva $\cdot$ Elvira Sales-Baptista
}

Received: 28 September 2012/ Accepted: 4 October 2013

(C) Springer Science+Business Media Dordrecht 2013

\begin{abstract}
Montados are agro-silvo-pastoral ecosystems, typical of the Southwest Iberian Peninsula, of high socio-economic and conservation importance, where grazing is a dominant activity. Montados are characterized by an open tree canopy of Quercus $s p$. and a diverse undercover of shrubs and grasslands that constitute the plant food resources for grazing animals. Plant food resources of Montados are highly variable, both spatially and seasonally, in quantity and quality. Reliable and easy to use methods to monitor grazing are necessary to allow proper understanding of foraging strategies of grazing animals and to set sustainable grazing management. We describe the main characteristics of the plant food resources available for grazing animals, striking its variability, and revise the potential of using $\mathrm{N}$-alkanes and saliva
\end{abstract}

M. I. Ferraz de Oliveira $(\bowtie)$

Instituto de Ciências Agrárias e Ambientais

Mediterrânicas (ICAAM), Universidade de Évora,

7002554 Évora, Portugal

e-mail: mifo@uevora.pt

E. Lamy

ICAAM and Química Orgânica, Produtos Naturais e Agro-Alimentares (QOPNA), Universidade de Aveiro, Aveiro, Portugal

e-mail: ecsl@uevora.pt

M. N. Bugalho

Centro de Ecologia Aplicada Prof. Baeta Neves, Instituto

Superior Agronomia, Lisbon, Portugal

e-mail: migbugalho@isa.utl.pt proteome methods to assess foraging strategies in Montados. In a scenario of dynamic multiple choices, we discuss the use of $n$-alkane methodology for the simultaneous estimation of diet composition and voluntary intake and saliva proteome as a mean of increasing the knowledge on diet adjustments.

Keywords Montado/Dehesa - Agro-silvopastoral systems · Grazing ecology $\cdot$ Foraging behavior $\cdot N$-alkanes $\cdot$ Salivary proteins

\section{Introduction}

Open Mediterranean oak woodlands, known as Montado in Portugal and Dehesa in Spain are a dominant agro-silvo-pastoral system of southwest Iberian

M. Vaz · F. Capela e Silva

ICAAM and Departamento de Biologia, Universidade de

Évora, Évora, Portugal

e-mail: mvaz@uevora.pt

F. Capela e Silva

e-mail: fcs@uevora.pt

C. Pinheiro - M. Cancela d'Abreu - E. Sales-Baptista ICAAM and Departamento de Zootecnia, Universidade de Évora, Évora, Portugal

e-mail: ccp@uevora.pt

M. Cancela d'Abreu

e-mail: abreu@uevora.pt

E. Sales-Baptista

e-mail: elsaba@uevora.pt 
Peninsula where they cover $\sim 3.1$ million ha (Díaz et al. 1997). This human shaped ecosystem is characterized by an open tree canopy of Quercus ilex spp. rotundfolia and Quercus suber and a diverse undercover of shrubs and grasslands, sometimes intermixed with agricultural crops, grazed by domestic and wild herbivore species.

Livestock production is a dominant activity and one of the most important sources of income to rural communities in Montados (Pinto Correia 1993; Bugalho et al. 2011). Grazing by domestic and wild species, associated with agricultural and forest management practices, characterize the complexity of these agro-silvo-pastoral systems (Fig. 1).

Traditionally, Montados were grazed continuously by sheep as single or mixed grazing with goats, under a shepherd's guidance (Plieninger and Wilbrand 2001). Recently, however, grazing by cattle, which is less labour intensive, has increased substantially. For example, in Portugal cattle grazing almost duplicated in the last decade (INE 1990, 2000, 2006) mainly due to funding schemes of the Common Agricultural Policy of the European Union which favour payments per cattle head. Grazing by pigs, namely Iberian pig production also increased both in Portugal Montados and Spain Dehesas, due to the high revenue of traditional pig-delicatessen products. Additionally, grazing by wild species is also common. For example, grazing by red deer (Cervus elaphus), wild boar (Sus scrofa) and wild rabbits (Oryctolagus cuniculus) is common in many Montados and Dehesas where these species are important sources of revenue through hunting (Bugalho et al. 2009).

Free grazing animals feeding on Montados face a highly variable (quantity and quality) plant food resource. High seasonal and spatial variability of species composition characterize the vegetation communities of the Montado, particularly grasslands. Such variability is strongly determined by a typical Mediterranean climate of hot and dry summers and mild and wet winters (Fig. 2). Most grassland species are annual species that set seed and die in summer and which growth peaks at the end of spring. Highly variable and usually low precipitation implies low potential for annual herbage production. In addition, the evergreen and sclerophyllous foliage of shrubs and

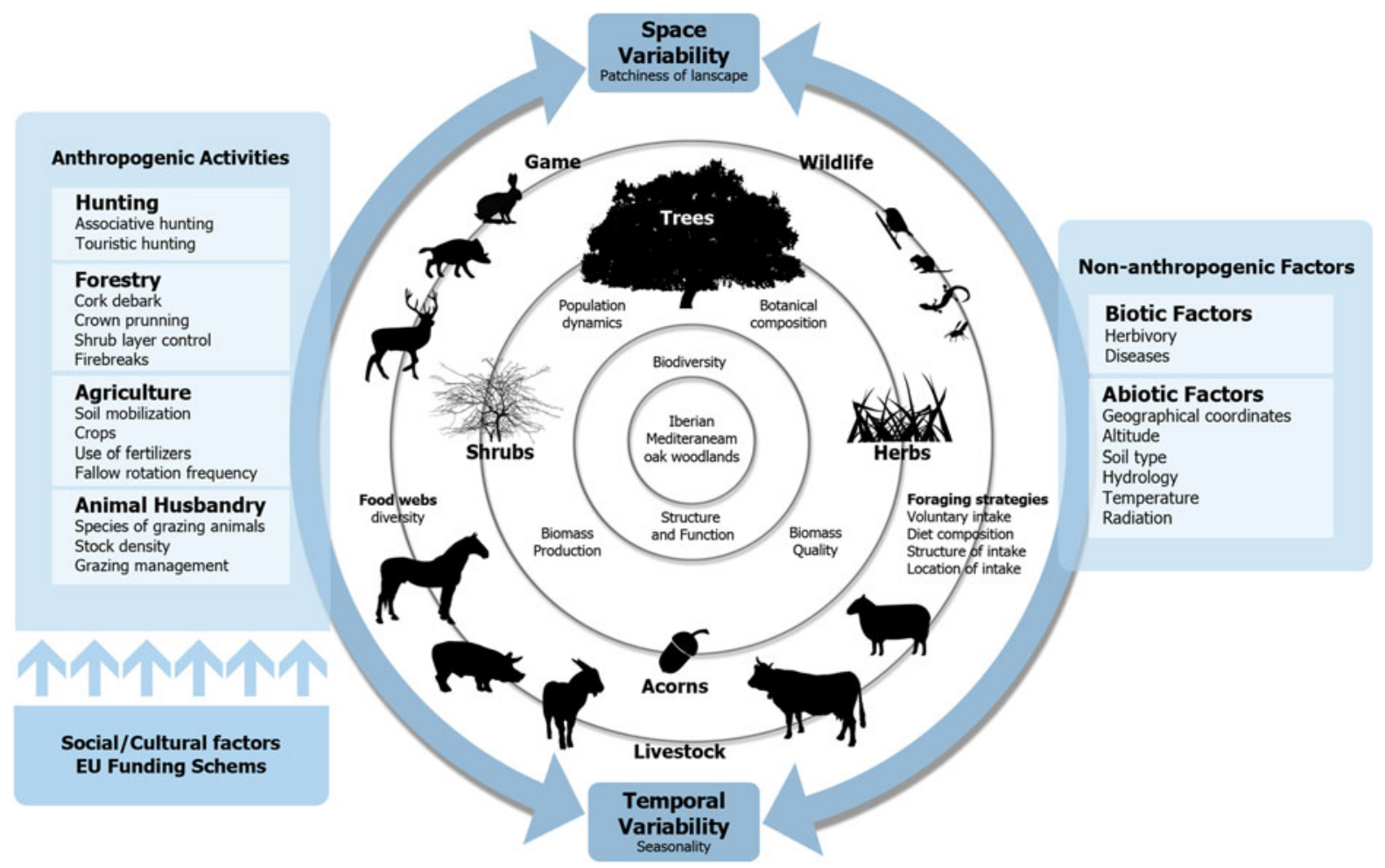

Fig. 1 Conceptual diagram of Montado interactions and key-characteristics 


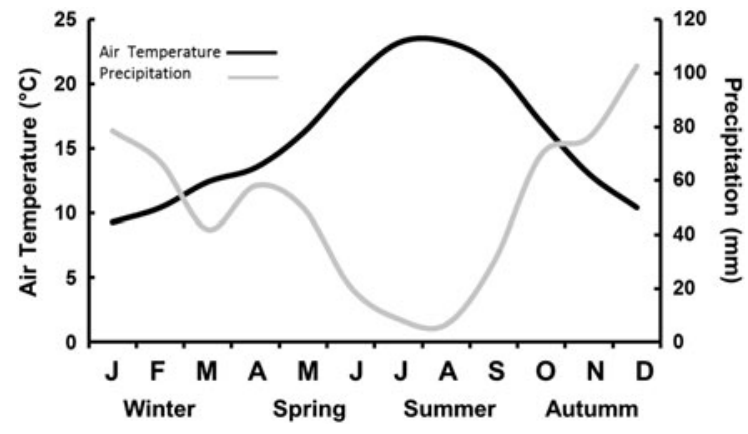

Fig. 2 Seasonal variation of average temperature and precipitation (Climate normals: 1971-2000, South-East Portugal: $38^{\circ}$ $57^{\prime} \mathrm{N}, 7^{\circ} 9^{\prime} \mathrm{W}$ ) (IMP 2012), where the Montado agro-silvopastoral system is a dominant land-use

trees, an important source of food to livestock in the Mediterranean region, usually have high levels of plant secondary metabolites (PSMs) (Vaz et al. 2010) which act as chemical defences against herbivores grazing Montados.

Effective grazing management in Montados requires a thoroughly understanding of the foraging strategies of grazing animals. That is, answering question such as: what, how much, when and where do animals feed (Fig. 3). Knowing diet composition and food intake is essential for balancing food availability, animal needs and potential effects of grazing on the ecology of the system. As in other Mediterranean systems, either overgrazing with negative effects on oak regeneration or undergrazing with consequent shrub encroachment and high risk of wildfire must be avoided for adequate conservation of Montados (Bugalho et al. 2011). For assessing diet quality and intake, accurate but simple methods, that may be applicable to the individual or population scales, are needed.

In this paper we (1) describe the characteristic variability of the plant food resources on offer to grazing animals in Montados and their related grazing behaviour (2) revise the use of $n$-alkanes from the plant cuticular wax as markers to evaluate diet composition and voluntary food intake of grazing animals in Montados and (3) discuss the use of salivary proteins to expand the understanding of diet composition of animals grazing these agro-silvo-pastoral systems.

\section{Key-characteristics of the plant food resources of Montado}

Temporal and spatial diversity of the plant food resources

As in other Mediterranean systems (Seligman 1996), the Montado is characterized by large spatial and temporal variation in the availability and quality of plant forage. High seasonal fluctuations of light, temperature and soil moisture drive plant quality and availability. Plant food resource quality is strongly related to species composition, namely abundance of legumes or grasses and overall plant diversity (Pérez-Ramos et al. 2008), which can be high in Montado grasslands. For example, over 135 different species of vascular mature plants per 0.1 ha have been reported in Montado or Dehesas (DíazVilla et al. 2003). Most of these species are annuals

Fig. 3 Components of the foraging strategy of herbivores, methodologies for their study and responses obtained (adapted from Gordon 1995)

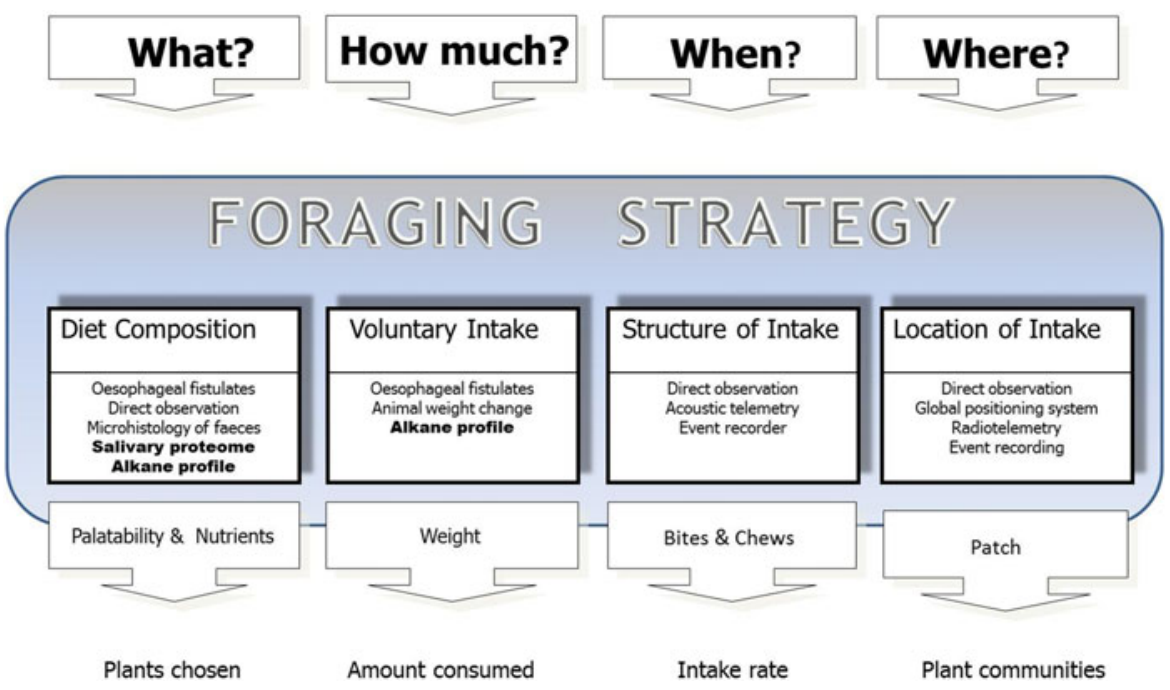


which germinate according to yearly environmental conditions (e.g. temperature, rainfall). Consequently, the species composition of grasslands in Montados can be highly variable among years. As an example, Table 1 reports the most representative species of herbs, shrubs and trees in an open Montado in South-East Portugal.

A high diversity of plant species implies that more palatable plants potentially coexist with less palatable plants, such as those presenting defensive traits either structural (e.g. thick bark, waxy coverings, hardy leaves, lignified or thorny stems) or biochemical (e.g. PSMs, responsible for plant toxicity, astringency and aversive taste). Additionally, herb plant biomass varies sharply seasonally (Fig. 4). Plant biomass peaks in late spring and restarts growing again after first autumn rains which may occur as early as September or as late as November (Seligman 1996). Lack of water and high temperatures during summer are the main limiting factors for plant biomass production (Vaz et al. 2010). Variability of herb biomass is also related to changes in the cover of dominant species, predominantly annual grasses (Poaceae) and legumes (Fabaceae). Grasses usually represent $40-60 \%$ of the total green herb biomass whilst legumes, are usually much less abundant all year round. In summer most annuals set seed and die and green herbage is practically unavailable. For example, the proportion of live green plant material can decrease from 74 to $0 \%$ of the herb biomass between June and September (Fig. 5) (Bugalho and Milne 2003; Cancela d'Abreu 1992).

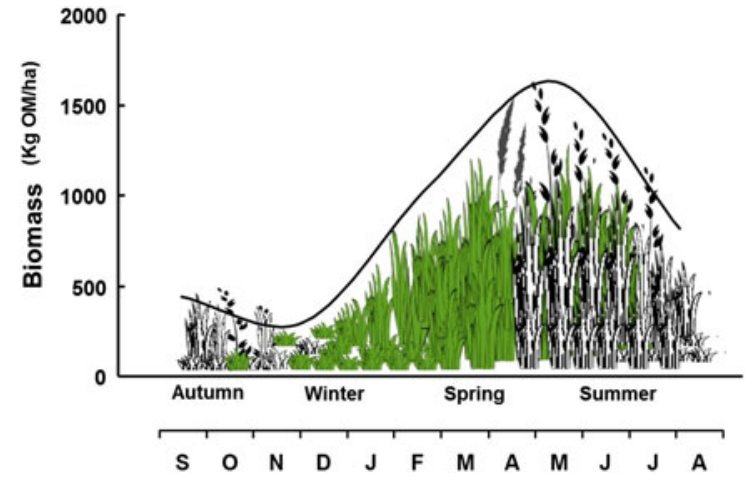

Fig. 4 Seasonal variation of a natural pasture biomass according to phenological stages recorded in a Montado ecosystem of South-East Portugal (data from Cancela d'Abreu 1992)

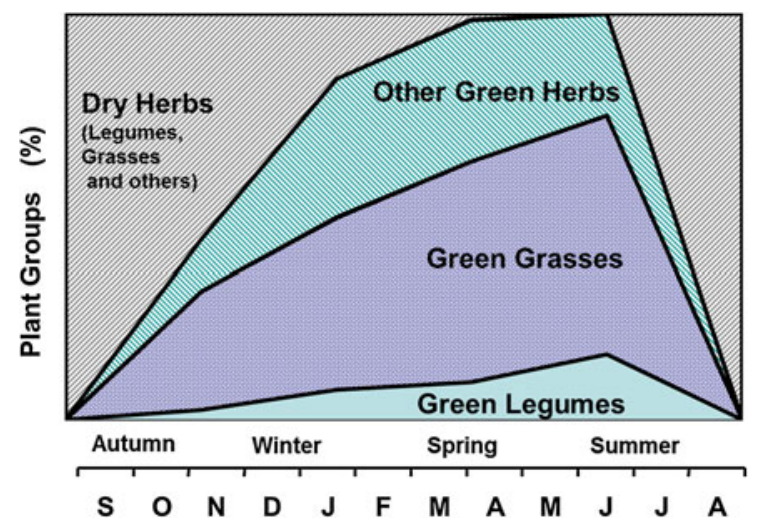

Fig. 5 Seasonal variation of the proportions of herb groups in a natural pasture at a Montado ecosystem (data from Cancela d'Abreu 1992)

Table 1 Diversity of plant species recorded in a Montado of South-East Portugal (adapted from Cruz 2002; Bugalho et al. 2002)

\begin{tabular}{|c|c|c|c|c|}
\hline \multicolumn{3}{|l|}{ Herbs } & \multirow[t]{2}{*}{ Shrubs } & \multirow[t]{2}{*}{ Trees } \\
\hline Poaceae & Fabaceae & Others families & & \\
\hline Austrodanthonia richardsonii & Ornithopus compressus & Plantagro coronopus & Arbutus unedo & Q. ilex \\
\hline Avena barbata & Ornithopus pinnatus & Tolpis barbata & Cistus ladanifer & Q. suber \\
\hline Briza sp & Ornithopus sp & Xolantha guttata & Cistus salvifolium & Oleae europea var \\
\hline Bromus catharticus & Trifolium campestre & Hypochaeris glabra & Cistus crispus & sylvestris \\
\hline Corynephorus fasciculatus & Trifolium striatum & Plantagro bellardii & Cistus monspeliensis & \\
\hline Festuca arundinacea & Trifolium glomeratum & Chamaemelummixtum & Halimium & \\
\hline Phalaris aquatica & Vicia $s p$ & Rumex angiocarpus & Myrtus communis & \\
\hline Vulpia ciliata & & Linaria spartea & Phillyrea angustifolia & \\
\hline Vulpia geniculata & & Alendula arvensis & Pistacia lentiscus & \\
\hline \multirow[t]{2}{*}{ Vulpia myuros } & & & Quercus coccifera & \\
\hline & & & Rosmarinus officinalis & \\
\hline
\end{tabular}


High inter-annual variability in biomass production can also occur. For example, in a Montado in southern Portugal biomass production varied from $750 \mathrm{~kg}$ of dry matter (DM) in late spring (June) of a dry year to almost 3,000 kg DM in a wet year (Bugalho and Milne 2003). Production of herb biomass in Montados during drier years is typical of semi-desertic biomes but in more favourable rainfall years it is well within the range of herb biomass production of the subhumid woodland-grassland biome (Naveh 1982).

Herbs and shrubs as plant food resources

The evergreen Mediterranean shrubs are another key plant food resource to herbivores feeding in Montados, particularly when the availability of herbs is low (autumn-winter) or of very low nutritive quality (summer).

Herbs and shrubs differ in growth patterns and plant structure, nutritional quality, resistance to chewing, fracture pattern and specific gravity after swallowing (Specht and Rundel 1990). Consequently, these plant groups present different challenges to feeding herbivores mainly in accessibility and ingestibility.

Mediterranean herbs and shrubs face herbivory and summer drought differently. Herbs have an escaping strategy (Chaves et al. 2002): they are mostly annual species that complete their life cycle before summer, producing seeds and remaining in the pasture as a dry high fibre food resource. Contrastingly, shrub (and tree foliage) are mainly evergreen species that prevent herbivory through avoiding strategies by reallocating energy in PSMs (Llusia et al. 2006), namely tannins, which are associated with toxicity and bitter taste.

Herbs and shrubs also differ in nutritive quality. Usually the crude protein content of herbs decreases from winter to summer, while its fibre content increases (Fig. 6a, b). These changes affect plant flavour and texture and ultimately voluntary food intake (Forbes 2007), which usually decreases during this period. During summer, the most limiting season to animal productivity in the Mediterranean region (Seligman 1996), herbs have a higher content in fibre and, contrastingly, shrubs and tree foliage became potential providers of protein (Fig. 6). Evergreen plants are particularly rich in PSMs, mainly tannins (Rogosic et al. 2006) (Fig. 6c), which may affect their related taste and ultimately food intake. Following summer, autumn and winter may also be seasons of scarcity, due to low availability of plant food, namely herb biomass. During this season, oak acorns, which have low fibre and high content of starch and fat, are the unique energetic food resource available in Montado.

\section{Key characteristics of foraging behaviour of herbivores in Montado}

High structural and chemical heterogeneity of the plant food resources imply that each herbivore species
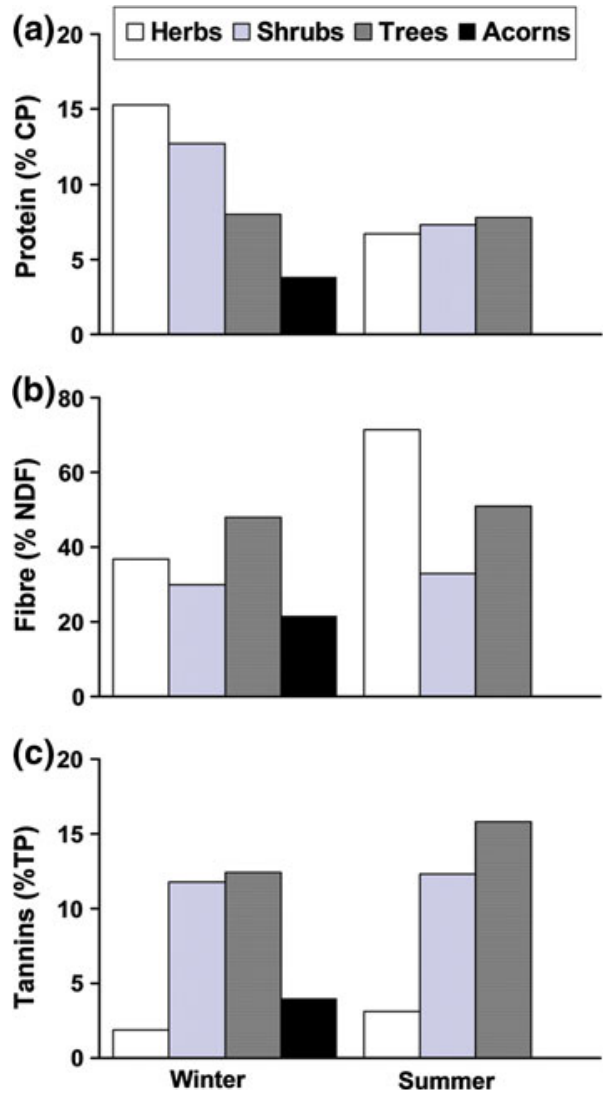

Fig. 6 Seasonal variation of main nutritional attributes of plant food resources in Montado: protein (a), fibre (b) and tannins (measured as total phenolics, Folin-Ciocalteu assay) (c) in natural pasture (Cancela d'Abreu 1992; Fraisse et al. 2007), shrub (C. ladanifer, Sales-Baptista, unpublished data) tree leaves (Q. ilex, Sales-Baptista 2001) and acorn kernel (from $Q$. ilex, Ferraz de Oliveira et al. 2012). Data on herb stratum was from a multispecific permanent pasture; data on $C$. ladanifer leaves were used as a shrub example; tree leaves and acorn kernel data were from $Q$. ilex trees. Data were obtained from samples collected under Montado (South of Portugal), except for tannin herbs content which refers to a permanent pasture from the Massif Central, France 
may satisfy their nutritional requirements within the same range of the plant species on offer. When grazing in the same sward, herbivore diets can overlap or diverge and feeding competition or complementarity occur according to the feeding style of each species that is "the animal specialization in the consumption of a particular type of food" (Pérez-Barberia and Gordon 2001; Mysterud et al. 2001; DeMiguel et al. 2008). Herbivores are usually classified into three groups: browsers (those that feed predominantly in shrub and tree foliage), grazers (those that feed predominantly on grasses) and mixed or intermediate feeders (those that feed both in shrub and tree foliage or grasses according to seasonal availability) (Hofmann and Stewart 1972). In the Montado, domestic herbivores as sheep, cattle and horses are mainly grazers whilst deer and goats, which shift their diets between shrubs and tree foliage, and grass, are intermediate feeders. Other common species such as wild rabbit are mainly grazers, and free-ranging Alentejano pigs and wild boars are omnivorous, consuming mainly grass and oak acorns (RodríguezEstévez et al. 2009).

Evolutionary diet specialization is not the only source of variation in dietary choice. Even animals of the same species, age, sex, weight and physiological state can show different foraging strategies (Fig. 3), defined as "the suite of decision-making processes in a particular feeding situation" (Gordon 1995). Main decisions address the quality and quantity of food ingested.

A common feature to all feeding style groups (browsers, grazers or intermediate feeders) is that they have to recognize, select and utilize a particular food item among those available in the environment, that is, they all select their diets. Diet selection is driven by factors that include recognition and ingestion of preferred food items, consequences of ingesting particular food items and remembrance of sensory cues associated with plant nutritional quality (see Provenza and Cincotta 1993 for a review). Among the mechanisms involved in the perception of food stimuli the sense of taste is crucial. Animals prefer sweet, salty and umami, which are usually associated to high nutritive quality diets and avoid sour and bitter which are related to toxic/antinutritive substances (Behrens and Meyerhof 2011). Thermal and mechanical sensations may also affect dietary choices. An example is astringency caused by dietary tannins, which may acts as feeding deterrents (Clauss et al. 2003). Differences in nutritive quality, including defensive traits, between browse and grasses also affect foraging strategies.

Another important aspect of foraging strategies is voluntary food intake which in Montado can be highly variable (Table 2) and not always correlate with availability of plant biomass. For instance, goats may increase digestible organic matter intake in Montado when forage availability decreases (Table 2). This occurs particularly when dietary intake shifts from herbage to shrubs. Shrubs have a fibre fraction with high lignin content ( $25 \%$ of total fibre) and its feeding particles are smaller and denser, allowing an increased passage rate through the digestive tract and therefore an increased food intake (Duncan and Poppi 2008). Frequently, the evergreen shrubs and tree foliage of the Montado are the main source of crude protein during the Mediterranean summer and browsers and mixed feeders prefer browse food during this season to overcome low nutritive quality of herbs. For instance, red deer (Bugalho and Milne 2003), and goats (Sales-Baptista 1995) have a predominantly browse diet in Montados during summer. Not all herbivore species, however, have the ability to overcome the low nutritive quality of herb biomass during summer and may reduce intake. For instance, sheep reduces intake both in quantity and quality during summer in Montado (Table 2).

Foraging strategies depend on the dynamic adaptations of herbivores in response to the environment where they live and their study must be accomplished by methodologies that could reflect those adaptive changes and modifications of behaviour. In particular, it is important to understand diet composition and voluntary food intake.

\section{Assessing diet composition and voluntary food intake in Montado}

Measuring diet composition and intake of herbivores is a major challenge, especially in complex vegetation systems (Dove and Mayes 1996) such as Montado. In simple and homogeneous swards, grazing animals have less opportunity to choose. In these cases, obtaining a representative sample of the diet consumed is a relatively simple task. In contrast, in Montado, feeding selectivity and diet variation can be large and a representative sample of the diet more 
Table 2 Voluntary intake ( $\mathrm{g}$ DOM day ${ }^{-1} \mathrm{~kg}^{-1}$ live weight ${ }^{0.75}$ ) (average \pm SEM) of different animal species grazing in Montado pastures, as affected by season

\begin{tabular}{lllll}
\hline Periods & Sheep & Goats & Pigs & References \\
\hline Autumn & $35.6 \pm 1.9$ & - & - & Cancela d'Abreu (1992) \\
Winter & $35.2 \pm 1.6$ & - & - & Cancela d'Abreu (1992) \\
Early spring & $39.7 \pm 1.6$ & - & $7.3 \pm 2.0^{\mathrm{a}}$ & Cancela d'Abreu (1992)/Ferraz de Oliveira et al. (2007) \\
Late spring & $27.9 \pm 2.1$ & - & - & Cancela d'Abreu (1992) \\
Early summer & $18.9 \pm 1.7$ & $11.9 \pm 1.0$ & - & Sales-Baptista (1995) \\
Late summer & $17.1 \pm 1.6$ & $34.2 \pm 1.8$ & - & Sales-Baptista (1995)
\end{tabular}

DOM digestible organic matter, SEM standard error of the mean

${ }^{\text {a }}$ Estimated voluntary intake of pasture (without considering acorns)

difficult to obtain. Therefore, irrespectively of the methodology used to study foraging strategies, diet composition estimation should precede food intake assessment in complex vegetation systems.

Animal based methods using markers are among the most preferred techniques to assess diet composition and intake, because they reflect animal choices and mimic what animals really ingest (Dove and Mayes 1991; Gordon 1995; Mayes and Dove 2000). A marker is a distinctive inert chemical signature that allows the recognition of its presence in a mixture. Usually the relative concentration of markers increases along the digestive system while other chemical compounds are being absorbed. This increase depends on the digestive process, which is linked to plant characteristics. For example, in spring, in Mediterranean agro-silvo-pastoral systems, herbs have lower fiber content than in summer, and thus a higher digestibility, which results in higher faecal marker concentrations. This is the principle underlying the most widely used animal-based techniques, where food DM intake is derived from the estimation of faecal DM output and diet digestibility.

The use of external markers (e.g. $\mathrm{Cr}_{2} \mathrm{O}_{3}$ ) to estimate faecal output in combination with in vitro techniques to estimate digestibility has been the most frequent approach for the estimation of voluntary food intake (Parker et al. 1990). However, in addition to problems that may be associated with the accuracy of the referred markers, the use of in vitro techniques precludes the estimation of individual animal intake (Dove and Mayes 1996). The $n$-alkane technique overcomes those disadvantages and further allows the simultaneous estimation of diet composition, becoming a particularly valuable technique to measure foraging strategies in Montado context. To better understand the reasons behind dietary choices and to achieve a clearer picture of ingestive behavior, issues related with diet adaptations and preferences must also be addressed. Due to its dynamic nature, adapting rapidly to changes of dietary conditions, saliva proteome is a promising tool for increasing knowledge on diet adjustments, namely those related to tannin presence. Each of this approaches and applications to the Montado are discussed below.

Using $N$-alkanes to asses diet composition and food intake in Montado

The cuticular wax of most higher plants is predominantly comprised of a complex mixture of very long chain aliphatic lipids (Kunst and Samuels 2003). The compounds present in those mixtures vary according to plant species and, in a smaller extent, plant parts (Mayes and Dove 2000). Among them, $n$-alkanes with odd-numbered carbon chains in the range C21-C37, although not being the most abundant, have a widespread presence, a relative inertness and are easy to analyze. These characteristics have rendered them preferred to other markers in nutritional studies (Dove and Mayes 1991). Additionally, main plant food resources in Montado, have a contrasting $n$-alkane composition. Herbs tend to have a higher concentration of shorter chain alkanes (C25) while evergreen oaks foliage and shrubs tend to have higher concentrations of long chain alkanes (C27-C31) (Table 3). This distinct $n$-alkane composition allows differentiation within herb and browse species or even between plant functional groups such as browse and herbs (Table 3). 


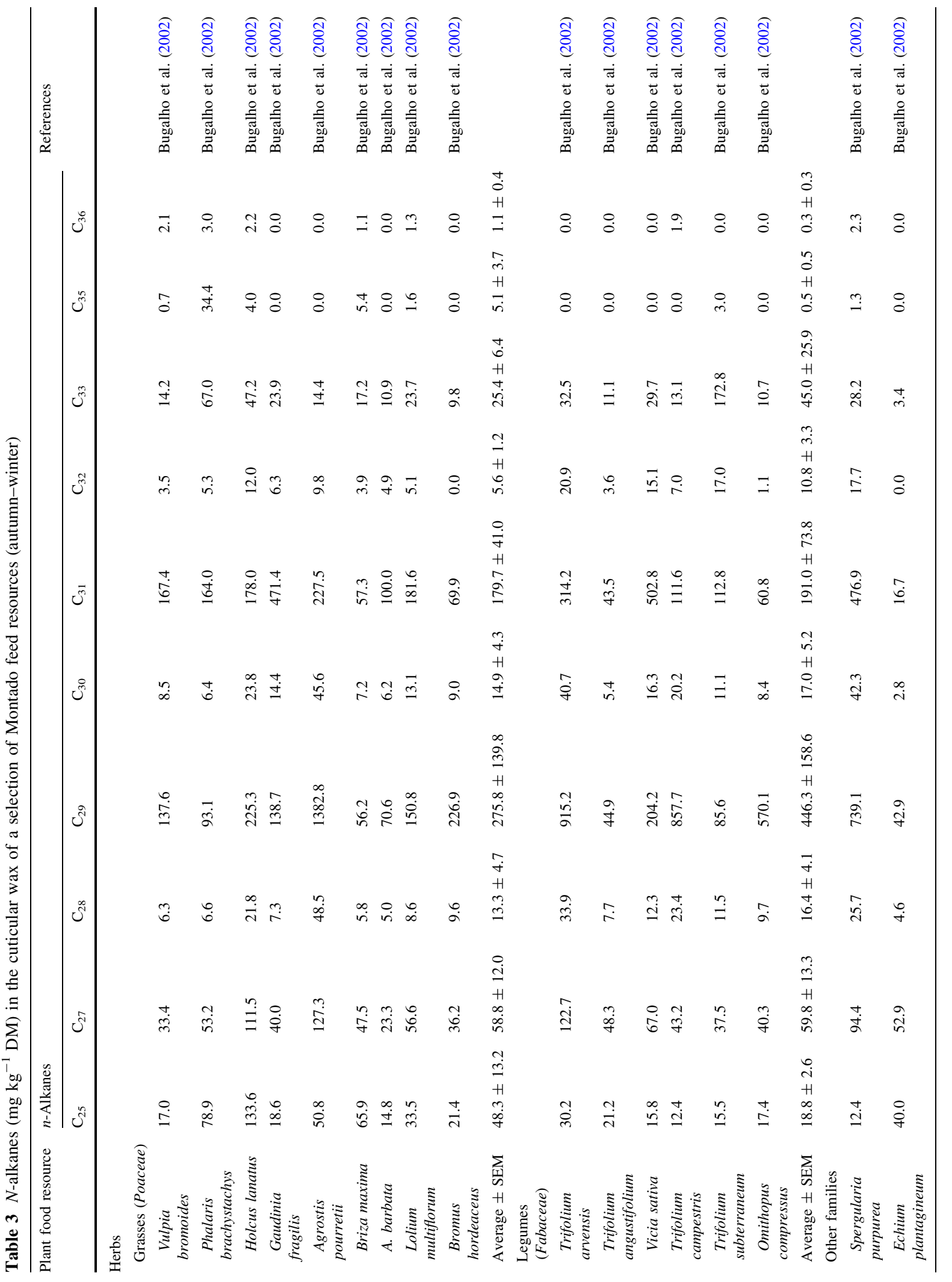




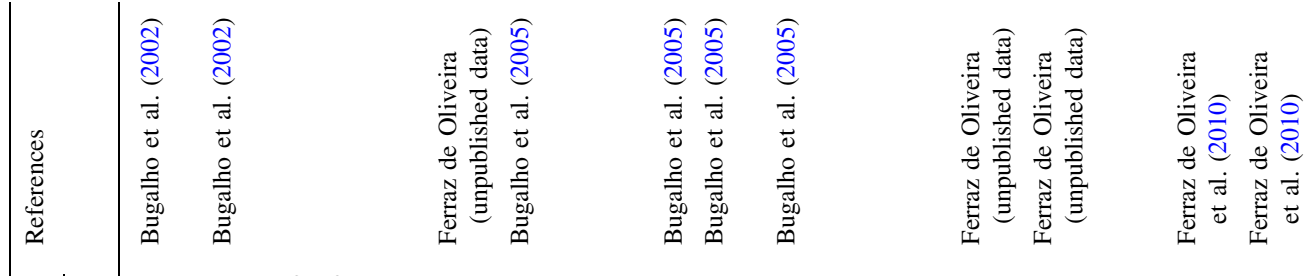

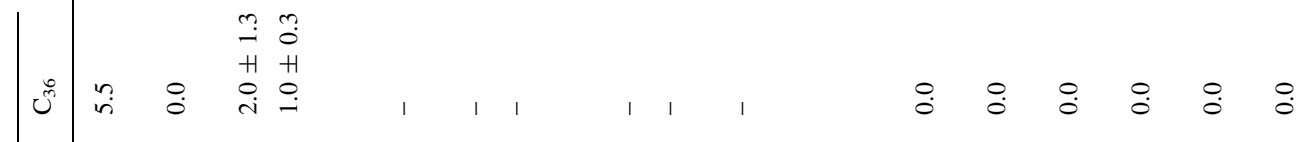

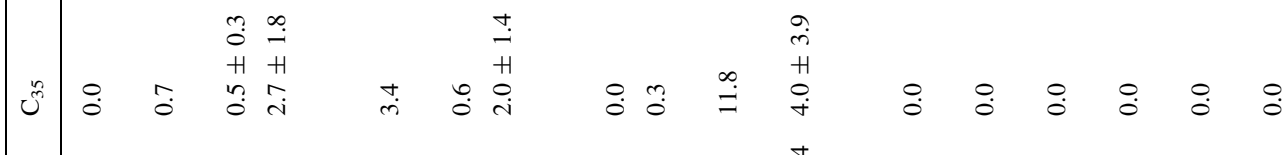

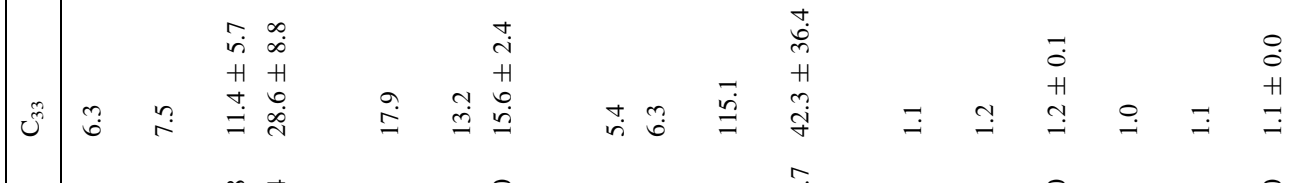

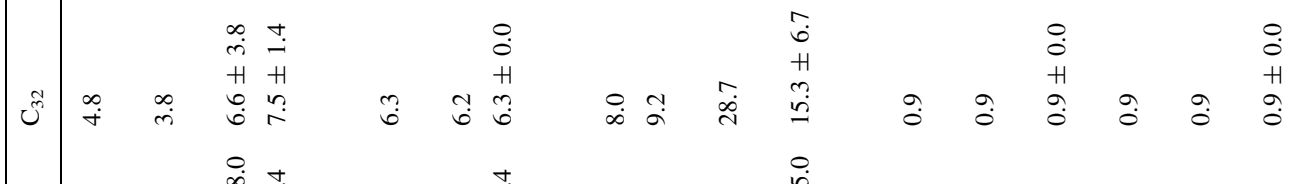

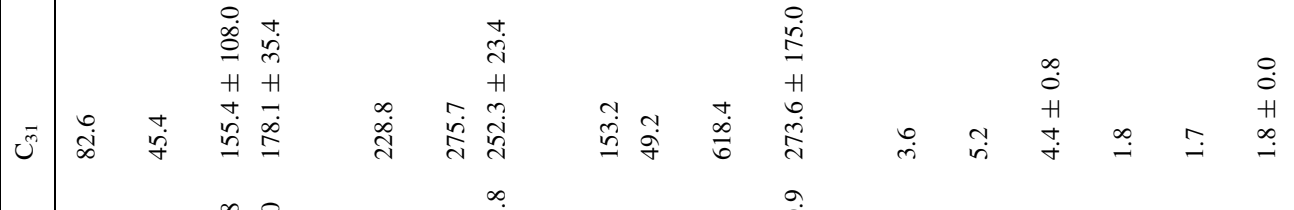

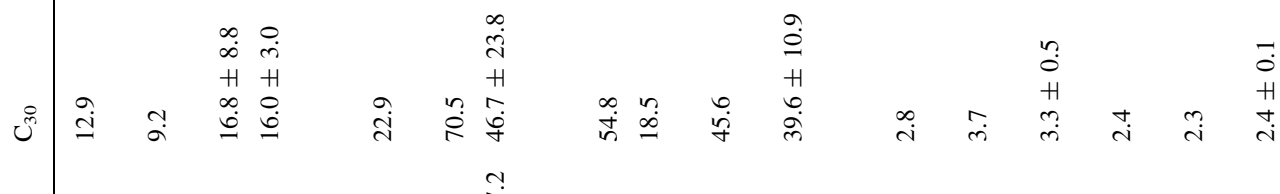

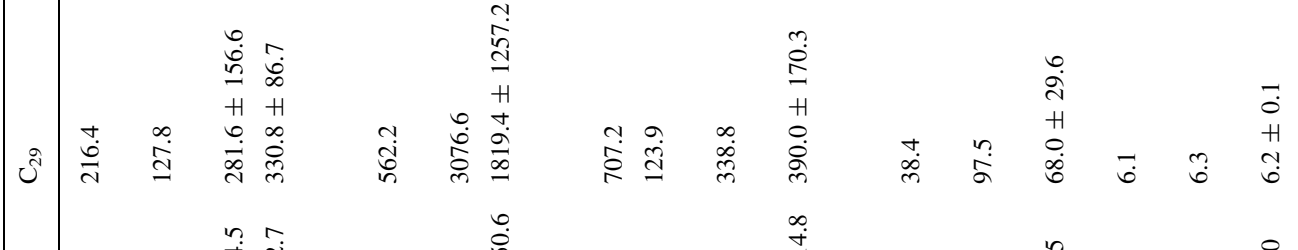

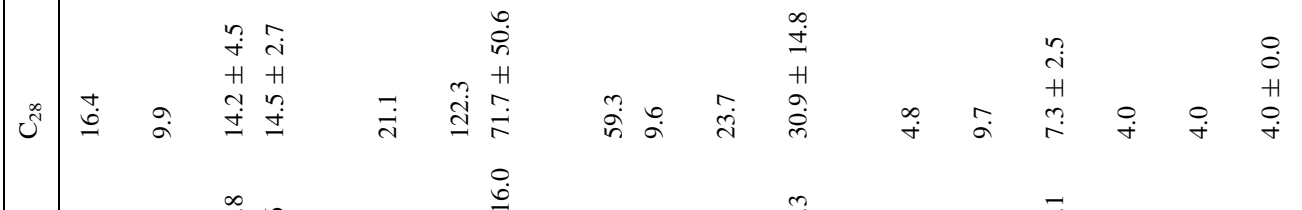

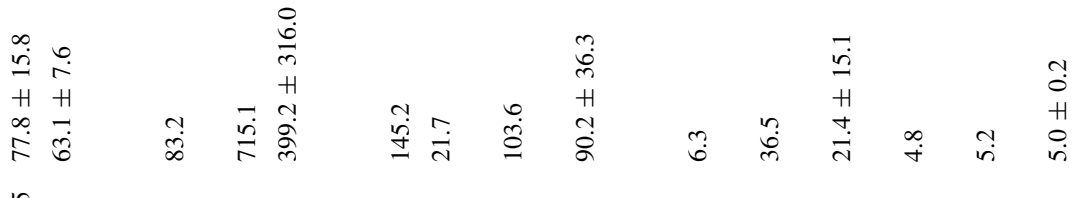

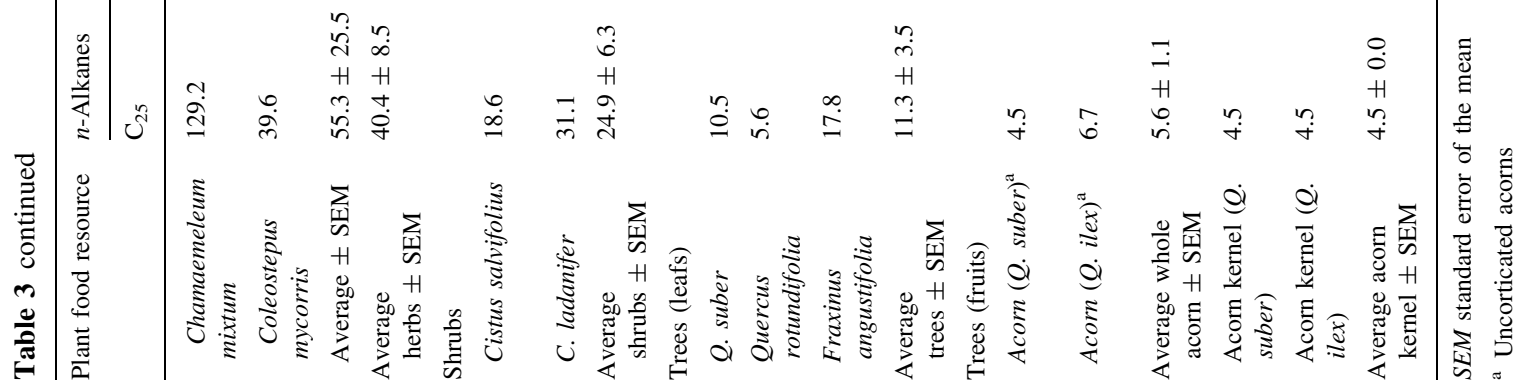


$N$-alkanes have been used to estimate the plant species composition of mixture of plants, extrusa from oesophagical-fistulated animals, digesta and herbivore faeces (Dove and Mayes 2005). This last method is one of the most used to estimate diet composition of free grazing animals (Dove and Mayes 2005). The use of the $n$-alkanes relies on the assumption that the $n$ alkane profile of a mixture of species results from the combination of the $n$-alkane profiles of the components of that mixture. Because faecal recoveries of $n$ alkanes, although generally high, are incomplete, when the sample in study is digesta or faeces, a correction for faecal recovery must be introduced (Mayes and Dove 2000).

The main drawback of using $n$-alkanes to estimate diet composition in Montado is the potentially very high number of dietary components that may occur in the diet of animals grazing this ecosystem. Apart from the different mathematical approaches (Dove 1992; Mayes et al. 1994; Dove and Moore 1995; Martins et al. 2002a; Barcia et al. 2007) which can be used to overcome that limitation, other possible strategies include (i) to combine the discriminatory powers of the $n$-alkane method with other methods for estimating diet composition; (ii) to decrease the number of plant components to be discriminated by grouping species; (iii) to increase the number of markers in use (Mayes and Dove 2000). For example, microhistology has been used to identify the botanical composition of extrusa from oesophagical fistulated sheep feeding on grassland and shrublands (Salt et al. 1994). This information together with the $n$-alkane profile of extrusa was used subsequently to quantify the diet composition of sheep by comparing $n$-alkane profiles of sheep faeces with the $n$-alkane profiles of grasses and shrubs used by sheep and identified by microhistological analysis.

Reduction of the number of plant components to be discriminated in the diet may be achieved by grouping species based on their $n$-alkane profiles. For example, grasses and legumes have usually different ratios of the alkanes C29-C31 (Dove and Mayes 1991). The plant family criteria have been used to reduce the number of components to discriminate in the diet composition of Alentejano pigs grazing in a Mediterranean pasture. In this case, diet composition was expressed as the proportion of grasses, legumes and other plant families (Ferraz de Oliveira et al. unpublished data). Grouping dietary components has also been used to estimate diet composition of wild rabbits (Martins et al. 2002b) and of red deer (Bugalho et al. 2002) in Montados. In the case of red deer diet, for example, 19 grassland species were grouped together into a single dietary component-herbage layerbased on the similarity of their $n$-alkane profiles when compared to the browse species available to red deer in the study area. Grouping of species with very different $n$-alkane profiles, however, needs to be conducted carefully and may present shortcomings if herbivores are being selective within the grouped plant species (Bugalho et al. 2002).

The third strategy is to use other markers in addition to $n$-alkanes increasing the power of discriminating among species. Plant wax compounds such as longchain alcohols (LCA), very long-chain fatty acids (VLCFA) and alkenes have been suggested as diet composition markers in addition to $n$-alkanes (Mayes and Dove 2000; Bugalho et al. 2004; Ferreira et al. 2009). The use of LCA (Bugalho et al. 2004) and VLCFA (Ferreira et al. 2009), as additional plant wax markers has been shown to increase the discriminatory power between diet components, resulting in better estimations of diet composition (Bugalho et al. 2004). This approach may be particularly interesting for estimating, for example, the diet composition of Alentejano pigs feeding on acorns and grasslands in the Montado. During mastication, pigs decorticate the acorns very efficiently which results in a diet component (acorn kernel) with a very low concentration of $n$ alkanes (Table 3). Because LCA are present in acorn kernels in higher concentrations than $n$-alkanes (e.g. $\mathrm{C}_{24} \mathrm{OH}: 36 \mathrm{mg} \mathrm{kg}^{-1} \mathrm{DM} ; \mathrm{C}_{26} \mathrm{OH}: 13 \mathrm{mg} \mathrm{kg}^{-1} \mathrm{DM}$ and $\mathrm{C}_{28} \mathrm{OH}: 9 \mathrm{mg} \mathrm{kg}^{-1} \mathrm{DM}$, Ferraz de Oliveira, unpublished data), more accurate estimates of diet composition for pigs feeding in Montado may be obtained. A further advantage of joining wax markers as LCA and VLCFA to $n$-alkanes is that the laboratorial procedure for their extraction is an extension of that used for the $n$-alkanes increasing the synergy of using both type of markers (Dove and Mayes 2006).

Once diet composition has been established, DM intake can be estimated from diet digestibility and faecal output (Eq. 1). Faecal output is estimated through the dilution of an orally administrated marker (even carbon chain alkane, e.g. $\mathrm{C}_{36}$ ) considering the correction for eventual incomplete faecal recovery. Diet digestibility is estimated indirectly as (1-indigestibility). In turn, indigestibility is measured, on a 
DM basis, as the increase in the concentration of an indigestible dietary component (odd carbon chain alkane) between food and excreta (Mayes and Dove 2000).

Food intake $\left(\mathrm{kg} \mathrm{DM}_{\mathrm{day}}{ }^{-1}\right)$

$$
=\frac{\text { Faecal output }\left(\mathrm{kg} \mathrm{DM} \mathrm{day}^{-1}\right)}{1-\text { Diet digestibility }\left(\mathrm{g} \mathrm{kg}^{-1}\right)}
$$

where DM is dry matter.

The $n$-alkanes have been initially suggested by Mayes and Lamb (1984) as digestibility markers. Albeit the discrete chemical identity of these compounds, that ensures the quantification of the same entity in the food and in the excreta, their incomplete faecal recovery rendered them not ideal for estimating digestibility. The grasp of Mayes et al. (1986) that allowed the establishment of $n$-alkanes as food intake markers ( $\mathrm{M}$ in equation below) arrived when they realize that if animals were dosed with synthetic evenchain alkanes $(j)$, with a similar faecal recovery to the immediately adjacent natural odd-chain alkane $(i)$, then faecal output and diet digestibility could be estimated simultaneously (Eq. 2). The frequent dosage of synthetic $n$-alkanes may be conducted in different matrixes, however controlled releasing devices which bring a significant reduction in animal handling, have also been used (Dove and Mayes 2006).

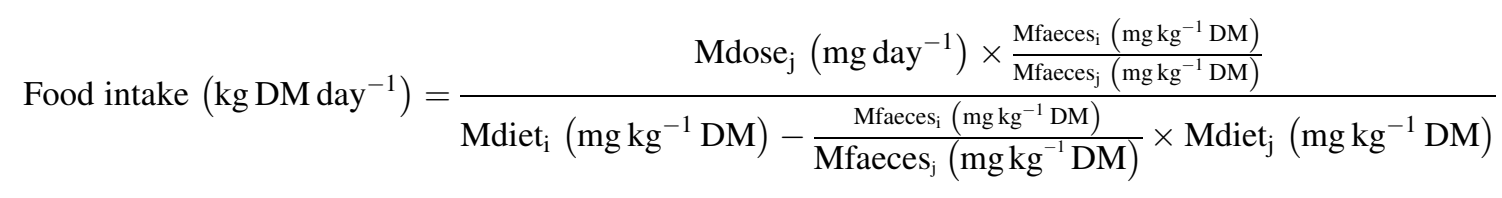

large number of plant species, using the same samples (plant and faeces) submitted to the same chemical determinations, when estimating diet composition and food intake is probably the greatest advantage of the $n$ alkane technique. These determinations allow individual estimations which are essential to assess variability of individual animal grazing behavior (Gordon 1995). The need to approach and restrain animals to dose synthetic alkanes for estimation of intake is not a limitation in the case of domestic animals grazing the Montado, which are familiarized with human presence and handling. Although using dosed $n$-alkanes in wild herbivores grazing the Montado may prove more difficult.

Enhancing the understanding of diet choices in the Montado using saliva proteome

Saliva plays an important role as a link in the relationship between diet and palatability. It also acts as a buffer against variations between the external and internal milieus of the animal. Therefore diet influences saliva and saliva influences taste perception (Christensen 1986) and indirectly foraging strategies.

During oral food processing, the physical properties of food are modified and the perception of flavour and texture are affected and mediated by saliva through a number of mechanisms (e.g. dilution of dietary compounds, interaction with dietary compounds, enzy- where DM is dry matter, Mdose is the marker dose, Mfaeces is the marker in faeces, Mdiet is the marker in diet, $\mathrm{i}$ is the natural odd-chain alkane, and $\mathrm{j}$ is the synthetic even-chain alkane.

The overall advantages of the $n$-alkane method to estimate herbivores food intake, over other techniques, have been extensively elucidated (see Dove and Mayes 2005 for an exhaustive review). Within the context of Montados, where animal diets include a matic activity and buffering capacity) (Salles et al. 2011). Saliva composition can change rapidly in response to oral stimuli (Proctor and Carpenter 2007). Thus, saliva has high plasticity and it is a fluid capable of a relatively rapid adaptation to different conditions, namely to the structure and composition of the food items ingested (Sales-Baptista et al. 2009). For example, parotid gland functional responses change in relation to moisture content of pastures (Scocco et al. 
2011) or to the amount of ingested dietary PSMs (Shimada 2006). Measuring the different components of saliva can thus be a very promising approach to investigate overall acceptability of food that is, the relationship between palatability and food choice. Among saliva components, proteins have been the most studied molecules because their diversity is directly related to most saliva functions (Helmerhorst and Oppenheim 2007).

The large dynamic range of protein nature and abundance within saliva can be measured using different proteomic techniques. Although salivary proteomics has been extensively studied in humans, mainly for diagnostic purposes (e.g. Spielmann and Wong 2011), in farm animals its study is only starting. Salivary proteome has been presented for sheep, goats, cattle and pigs mainly for nutrition and health purposes (Lamy and Mau 2012). Among the main proteomic techniques used in salivary proteome studies, two-dimensional electrophoresis stands as a powerful separation method for complex protein mixtures such as saliva. Thousands of different proteins can be separated, and information such as the isoelectric point, apparent molecular weight and relative amount of each protein can be obtained. As such, salivary protein profiling can be a powerful tool for diet palatability biomarker discovery and to investigate foraging behaviour. Different ruminant feeding styles (browser vs grazer) were related to differences in salivary proteome. For example goats and sheep differ in the expression level of several parotid salivary proteins, such as one isoform of carbonic anhydrase VI and some isoforms of clusterin precursor, among others (Lamy et al. 2008, 2009).

Until now, relationships between saliva and ruminant diet were only established for tannins (Lamy and Mau 2012). Domestic and wild herbivores feeding in Montados, particularly browsers, have to face plant species rich in tannins, namely shrubs, tree foliage and the oak acorns during the end of summer and beginning of autumn. Salivary biomarkers for tannins may be used for evaluating nutritional stress and assess seasonal shifting of foraging strategies.

Supportive evidence links the occurrence of tanninbinding salivary proteins (TBSPs) to the levels of tannins present in the individual's regular diet (for a review report to Shimada 2006). For instance, species thriving on low tannin plants as grazers, have little or none of such salivary proteins. Contrastingly, the presence of TBSPs has been reported as constitutive for browsers, and induced according to diet tannin content for intermediate feeders (Hagerman and Robbins 1993). However, for some domestic ruminant species, the presence of TBSPs is controversial (Table 4), which can be related to the adaptation of different animal breeds to different diet environments (Sales-Baptista et al. 2009). The affinity to bind tannins has been mostly associated with proline rich proteins (PRPs), which are the most well studied among the TBSPs (Shimada 2006). Lamy et al. (2008, 2009) were unable to identify PRPs in parotid saliva from sheep and goat breeds, commonly present in Montado. In the case of goats, which usually ingest higher levels of tannins, comparatively to sheep, this may suggest the existence of other defense mechanisms. In fact, the ability of ruminal microbes to produce secretions that reduce the effects of tannins (Chiquette et al. 1988) or to produce tannin-degrading enzymes (Brooker et al. 1999) has been reported for some tropical goat breeds. When dietary tannin levels were increased, the expression of other salivary proteins besides TBSPs and/or protein isoforms (cytoplasmic actin 1 and annexin A1) were altered (Lamy et al. 2011). These proteins may not bind to tannins, but they can result from an increased salivary gland function induced by tannins and therefore could act as biomarkers for tannin ingestion. The increase of cytoplasmic actin 1, which is a cytoskeleton protein, may be related to the particular "apocrine-like" mode of salivary secretion presented by ruminants (Stolte and Ito 1996). Consequently, a raise in salivation rate might result in an increased content of cytoplasm in the saliva. Additionally, annexin A1 expression has been reported to increase in response to bitter/sour solutions (Neyraud et al. 2006) which are tastes frequently associated with tannins and key plant food resources of Montado.

Although further information is needed for the particular case of Montado, relations between other salivary proteins and diet have been reported. For example the oligosaccharidic chains of salivary glycoproteins were associated to pasture characteristics (Scocco et al. 2006). The great variety of glycoconjugates can be related to their role in the absorption of nutritive substances and the protection of mucous membrane from chemical and/or physical agents. Saliva amino acid profile has also been suggested as a potential marker for identifying main plant species in 
Table 4 Presence of TBSPs in saliva of different animal species

\begin{tabular}{|c|c|c|c|}
\hline \multirow[t]{2}{*}{ Species } & \multicolumn{2}{|c|}{ Presence of TBSPs } & \multirow[t]{2}{*}{ References } \\
\hline & Constitutive $^{\mathrm{a}}$ & $\begin{array}{l}\text { Induced by } \\
\text { tannins }\end{array}$ & \\
\hline \multirow{2}{*}{$\begin{array}{l}\text { Sheep (Ovis } \\
\text { aries) }\end{array}$} & No & No & Robbins et al. (1987), Austin et al. (1989), Mole et al. (1990), Ammar et al. (2011) \\
\hline & $\begin{array}{l}\text { Yes } \\
\text { (unidentified) }^{\mathrm{c}}\end{array}$ & - & Vaithiyanathan et al. (2001) \\
\hline \multirow{2}{*}{$\begin{array}{c}\text { Cattle (Bos } \\
\text { taurus) }\end{array}$} & No & No & Robbins et al. (1987), Austin et al. (1989), Pérez-Maldonado et al. (1995) \\
\hline & - & $\begin{array}{l}\text { Yes } \\
(\text { other type })^{d}\end{array}$ & Makkar and Becker (1998), Gehrke (2001) \\
\hline \multirow[t]{3}{*}{$\begin{array}{l}\text { Goat (Capra } \\
\text { hircus) }\end{array}$} & No & & $\begin{array}{l}\text { Pérez-Maldonado et al. (1995), Distel and Provenza (1991), Alonso-Díaz et al. } \\
\text { (2010), Hanovice-Ziony et al. (2010) }\end{array}$ \\
\hline & $\begin{array}{l}\text { Yes } \\
\text { (unidentified) }\end{array}$ & - & Vaithiyanathan et al. (2001), Provenza and Malechek (1984), Burritt et al. (1987) \\
\hline & - & $\begin{array}{l}\text { Yes } \\
\text { (unidentified) }\end{array}$ & Alonso-Díaz et al. (2010) \\
\hline \multirow{2}{*}{$\begin{array}{l}\text { Pig (Sus } \\
\text { scrofa) }\end{array}$} & No & No & Mole et al. (1990) \\
\hline & Yes & - & Patamia et al. (2005) \\
\hline
\end{tabular}

${ }^{a}$ Presence in saliva under consumption of regular diets

b Presence in saliva following stimulation with tannin-rich diets

c Presence of unidentified TBSPs

d Presence of TBSPs other than PRPs

herbivore diets (Yisehak et al. 2012). Altogether, the available data suggest that changes in the expression of specific proteins as a response to specific dietary compounds ingested by the animal can be used as potential biomarkers of ingested plant species in complex systems such as Montados.

\section{Conclusion}

Grazing by domestic and wild herbivores is a dominant activity in the Montado agro-silvo-pastoral system. The plant food resources available to grazing animals are highly diverse and variable both spatially and seasonally. Accurate monitoring of animal foraging strategies, namely diet composition and dietary food intake, is a major challenge but is essential to generate information for the sustainable grazing management of Montados.

$N$-alkanes can be used for assessing the diet composition and voluntary food intake of animal grazing Montados. Dominant plant food resources such as browse and herb species have different $n$ alkane profiles allowing discrimination of such dietary components in animal diets. Distinctive $n$-alkane profiles between grasses and legumes also allow separation of these dietary components in the diets of animals feeding in Montado grasslands. The resulting discriminating power among groups of plants may be increased if other wax markers such as LCA are added. $\mathrm{N}$-alkanes, however do not allow assessment of short time ingestive behaviour. Salivary proteomics is a dynamic approach that allow using expression levels of particular proteins as markers for assessing, for example, the presence of tannins in the ingested diet. The presence of TBSP, such as PRPs, or cytoplasmic actin 1 and annexin A1 may be useful biomarkers, which can indicate the consumption of these PSMs. Salivary proteome may also potentially be used as a source of markers for other ingested dietary components, although this needs further investigation. $\mathrm{N}$-alkanes and salivary proteome provide useful data contributing for understanding foraging strategies of animals grazing Montados and other agro-silvo-pastoral systems.

Acknowledgments We thank two anonymous referees for their comments that greatly improved a previous version of the manuscript. This work was funded by FEDER Funds through 
the Operational Programme for Competitiveness FactorsCOMPETE and National Funds through FCT-Foundation for Science and Technology under the Strategic Projects PEst-C/AGR/UI0115/2011 and PEst-C/QUI/UI0062/2011. We acknowledge also the financial support from the Portuguese Science Foundation (FCT) in the forms of "Ciência 2008" research contracts of MI Ferraz de Oliveira and MN Bugalho, Post-Doctoral grants (SFRH/BPD/63240/2009 and SFRH/BPD/ 90668/2012) of E Lamy and MN Bugalho and Post-Doctoral grant within the research project ALENT-07-0224-FEDER001744 of MI Ferraz de Oliveira. The funding sources played no role in the development of the present work or upon its submission for publication.

\section{References}

Alonso-Díaz MA, Torres-Acosta JFJ, Sandoval-Castro CA, Hoste H (2010) Tannins in tropical tree fodders fed to small ruminants: a friendly foe? Small Rumin Res 89:164-167. doi:10.1016/j.smallrumres.2009.12.040

Ammar H, López S, Salem AZM, Bodas R, Gonzalez JS (2011) Effect of saliva from sheep that have ingested quebracho tannins on the in vitro rumen fermentation activity to digest tannin-containing shrubs. Anim Feed Sci Technol 163:77-83. doi:10.1016/j.anifeedsci.2010.10.007

Austin PJ, Suchar LA, Robbins CT, Hagerman AE (1989) Tannins-binding proteins in saliva of deer and their absence in saliva of sheep and cattle. J Chem Ecol 15:1335-1347. doi:10.1007/BF01014834

Barcia P, Bugalho MN, Campagnolo ML, Cerdeira JO (2007) Using $n$-alkanes to estimate diet composition of herbivores: a novel mathematical approach. Animal 1:141-149. doi: $10.1017 /$ S1751731107340068

Behrens M, Meyerhof W (2011) Gustatory and extragustatory functions of mammalian taste receptors. Physiol Behav 105:4-13. doi:10.1016/j.physbeh.2011.02.010

Brooker JD, O'Donovan LO, Skene I, Sellick G (1999) Mechanisms of tannin resistance and detoxification in the rumen. In: Bell CR, Brylinsky M, Johnson-Green P (eds) Microbial biosystems: new frontiers. Proceedings of the 8th international symposium on microbial ecology. Halifax, Canada

Bugalho MN, Milne JA (2003) The composition of the diet of red deer (Cervus elaphus) in a Mediterranean environment: a case of summer nutritional constraint? For Ecol Manage 181:23-29. doi:10.1016/S0378-1127(03)00125-7

Bugalho MN, Milne JA, Mayes RW (2002) The effects of feeding selectivity on the estimation of diet composition using the $n$-alkane technique. Grass Forage Sci 57:224-231. doi:10.1046/j.1365-2494.2002.00320.x

Bugalho MN, Dove H, Kelman W, Wood JT, Mayes RW (2004) Plant wax alkanes and alcohols as herbivore diet composition markers. J Range Manage 57:259-268

Bugalho MN, Milne JA, Mayes RW, Rego FC (2005) Plant-wax alkanes as seasonal markers of red deer dietary components. Can J Zool 83:465-473. doi:10.1139/z05-031

Bugalho MN, Plieninger T, Aronson J, Ellatifi M, Crespo DG (2009) Open woodlands: a diversity of uses (and overuses). In: Aronson J, Pereira JS, Pausas J (eds) Cork oak woodlands on the edge: ecology, biogeography, and restoration of an ancient Mediterranean ecosystem. Island Press, Washington, DC, pp 33-45

Bugalho MN, Caldeira MC, Pereira JS, Aronson J, Pausas JG (2011) Mediterranean cork oak savannas require human use to sustain biodiversity and ecosystem services. Front Ecol Environ 9:278-286. doi:10.1890/100084

Burritt EA, Malechek JC, Provenza FD (1987) Changes in concentrations of tannins, total phenolics, crude protein, and in vitro digestibility of browse due to mastication and insalivation by cattle. J Range Manage 40:409-411

Cancela d'Abreu M (1992) Food value of three annual pasture for sheep. PhD Dissertation, Universidade de Évora, Portugal (In portuguese)

Chaves MM, Pereira JS, Maroco J, Rodrigues ML, Ricardo CPP, Osório ML, Carvalho I, Faria T, Pinheiro C (2002) How plants cope with water stress in the field? Photosynthesis and Growth. Ann Bot 89:907-916. doi:10.1093/aob/ $\operatorname{mcf} 105$

Chiquette J, Cheng KJ, Costerton JW, Milligaln P (1988) Effect of tannins on the digestibility of two isosynthetic strains of birdsfoot trefoil (Lotus corniculatus L.) using in vitro and in sacco techniques. Can J Anim Sci 68:751-760. doi:10. 4141/cjas88-084

Christensen CM (1986) Importance of saliva in diet-taste relationships. In: Kare MR, Brand JG (eds) Interaction of the chemical senses with nutrition. Academic Press, London, pp 3-24

Clauss M, Lason K, Gehrke J, Lechner-Doll M, Fickel J, Grune T, Streich WJ (2003) Captive roe deer (Capreolus capreolus) select for low amounts of tannic acid but not quebracho: fluctuation of preferences and potential benefits. Comp Biochem Physiol B 136:369-382. doi:10.1016/ S1096-4959(03)00244-6

Cruz C (2002) Effect of anthropogenic activities on the dynamics of herbaceous and shrub communities in Montado system. M.Sc. Dissertation. Universidade de Évora, Portugal (In portuguese)

DeMiguel D, Fortelius M, Azanza B, Morales J (2008) Ancestral feeding state of ruminants reconsidered: earliest grazing adaptation claims a mixed condition for Cervidae. Evol Biol 8:13. doi:10.1186/1471-2148-8-13

Díaz M, Campos P, Pulido FJ (1997) The Spanish dehesas: a diversity of land use and wildlife. In: Pain D, Pienkowski M (eds) Farming and birds in Europe: the Common Agricultural Policy and its implications for bird conservation. Academic Press, London, pp 178-209

Díaz-Villa MD, Marañón T, Arroyo J, Garrido B (2003) Soil seed bank and floristic diversity in a forest-grassland mosaic in southern Spain. J Veg Sci 14:701-709. doi:10. 1111/j.1654-1103.2003.tb02202.x

Distel RA, Provenza FD (1991) Experience early in life affects voluntary intake of blackbrush by gotas. J Chem Ecol 17:431-450. doi:10.1007/BF00994343

Dove H (1992) Using the $n$-alkanes of plant cuticular wax to estimate the species composition of herbage mixtures. Aust J Agric Res 43:1711-1724. doi:10.1071/AR9921711

Dove H, Mayes RW (1991) The use of plant wax alkanes as marker substances in studies of the nutrition of herbivores: a review. Aust J Agric Res 42:913-952. doi:10.1071/ AR9910913 
Dove H, Mayes RW (1996) Plant wax components: a new approach to estimating intake and diet composition in herbivores. J Nutr 126:13-26

Dove H, Mayes RW (2005) Using $n$-alkanes and other plant wax components to estimate intake, digestibility and diet composition of grazing/browsing sheep and goats. Small Rumin Res 59:123-139. doi:10.1016/j.smallrumres.2005. 05.016

Dove H, Mayes RW (2006) Protocol for the analysis of $n$ alkanes and other plant-wax compounds and for their use as markers for quantifying the nutrient supply of large mammalian herbivores. Nat Protoc 1:1-18. doi:10.1038/ nprot.2006.225

Dove H, Moore AD (1995) Using a least-squares optimisation procedure to estimate botanical composition based on the alkanes of plant cuticular wax. Aust J Agr Res 46: 1535-1544. doi:10.1071/AR9951535

Duncan AJ, Poppi DP (2008) Nutritional ecology of grazing and browsing ruminants. In: Gordon IJ, Prins HHT (eds) The ecology of browsing and grazing. Springer, Berlin, pp 89-116

Ferraz de Oliveira MI, Cancela d'Abreu M, Freitas AB (2007) The effect of polyethylene glycol (PEG) on protein output of free range Alentejano pigs. In: Nanni Costa L, Zambonelli P, Russo V (eds) Proceedings of the 6th international symposium on the Mediterranean pig. Messina, Capo d'Orlando (ME), Italy, pp 236-239

Ferraz de Oliveira MI, Machado MG, Cancela d'Abreu M (2010) $N$-alkane profile of acorns from Quercus rotundifolia and Quercus suber. In: 7th international symposium on the Mediterranean Pig, Cordoba, Spain, pp 54

Ferraz de Oliveira MI, Machado MG, Cancela d'Abreu M (2012) Acorn chemical composition depending on shedding date and Quercus species. Options Mediterr A 101:229-234

Ferreira LMM, Carvalho S, Falco V, Celaya R, García U, Santos AS, Rodrigues MAM, Osoro K (2009) Assessment of very long-chain fatty acids as complementary or alternative natural fecal markers to $n$-alkanes for estimating diet composition of goats feeding on mixed diets. J Anim Sci 87:2732-2745. doi:10.2527/jas.2008-1718

Forbes JM (2007) Voluntary food intake and diet selection in farm animals, 2nd edn. Cab International, Wallingford

Fraisse D, Carnat A, Viala D, Pradel P, Besle J-M, Coulon J-B, Felgines C, Lamaison J-L (2007) Polyphenolic composition of a permanent pasture: variations related to the period of harvesting. J Sci Food Agric 13:2427-2435. doi:10. $1002 /$ jsfa. 2918

Gehrke J (2001) Investigations of tannin-binding salivary proteins of roe deer and other ruminants. PhD Dissertation, University of Potsdam, Potsdam, Germany (In german with English summary)

Gordon IJ (1995) Animal-based techniques for grazing ecology research. Small Rumin Res 16:203-214. doi:10.1016/ 0921-4488(95)00635-X

Hagerman AE, Robbins CT (1993) Specificity of tannin-binding salivary proteins relative to diet selection by mammals. Can J Zool 71:628-633. doi:10.1139/Z10-064

Hanovice-Ziony M, Gollop N, Landau SY, Ungar ED, Muklada H, Glasser TA, Perevolotsky A, Walker JW (2010) No major role for binding by salivary proteins as a defense against dietary tannins in Mediterranean goats. J Chem Ecol 36:736-743. doi:10.1007/s10886-010-9809-z

Helmerhorst EJ, Oppenheim FGJ (2007) Saliva: a dynamic proteome. Dent Res 86:680-693. doi:10.1177/15440591 0708600802

Hofmann RR, Stewart DRM (1972) Grazer or browser: a classification based on the stomach structure and feeding habits of East African ruminants. Mammalia 36:226-240

IMP (2012) Inst. de Meteorologia de Portugal. http://www. meteo.pt/pt/oclima/clima.normais/007/. Accessed 25 May 2012

INE (1990) Instituto Nacional de Estatística. Recenseamento Geral Agrícola, 1989. INE (ed) IP, Lisboa, Portugal

INE (2000) Instituto Nacional de Estatística. Recenseamento Geral Agrícola, 1999. INE (ed), IP, Lisboa, Portugal

INE (2006) Instituto Nacional de Estatística. Inquérito à estrutura das explorações agrícolas, 2005. INE (ed), IP, Lisboa, Portugal

Kunst L, Samuels AL (2003) Biosynthesis and secretion of plant cuticular wax. Prog Lipid Res 42:51-80

Lamy E, Mau M (2012) Saliva proteomics as an emerging, non-invasive tool to study livestock physiology, nutrition and diseases. J Proteomics. doi:10.1016/j.jprot.2012. 05.007

Lamy E, da Costa G, Capela e Silva F, Potes J, Coelho AV, Baptista ES (2008) Comparison of electrophoretic protein profiles from sheep and goat parotid saliva. J Chem Ecol 34:388-397. doi:10.1007/s10886-008-9442-2

Lamy E, da Costa G, Santos R, Capela e Silva F, Potes J, Pereira A, Coelho AV, Sales Baptista E (2009) Sheep and goat saliva proteome analysis: a useful tool for ingestive behavior research? Physiol Behav 98:393-401. doi:10. 1016/j.physbeh.2009.07.002

Lamy E, da Costa G, Santos R, Capela e Silva F, Potes J, Pereira A, Coelho AV, Sales Baptista E (2011) Effect of condensed tannin ingestion in sheep and goat parotid saliva proteome. J Anim Physiol Anim Nutr (Berl) 95:304-312. doi:10. 1111/j.1439-0396.2010.01055.x

Llusia J, Penuelas J, Alessio GA, Estiarte M (2006) Seasonal contrasting changes of foliar concentrations of terpenes and other volatile organic compound in four dominant species of a Mediterranean shrubland submitted to a field experimental drought and warming. Physiol Plantarum 127:632-649. doi:10.1111/j.1399-3054.2006.00693.x

Makkar HPS, Becker K (1998) Adaptation of cattle to tannins: role of proline-rich proteins in oak-fed cattle. Anim Sci 67:277-281. doi:10.1017/S1357729800010031

Martins H, Elston DA, Mayes RW, Milne JA (2002a) Assessment of the use of $n$-alkanes as markers to describe the complex diets of herbivores. J Agric Sci 138:425-434. doi:10.1017/S0021859602002046

Martins H, Milne JÁ, Rego F (2002b) Quantification of the seasonal and spatial variation in the diet of a wild rabbit population in a Southern Portuguese Montado. J Zool 258:395-404. doi:10.1017/S0952836902001541

Mayes RW, Dove H (2000) Measurement of dietary nutrient intake in free-ranging mammalian herbivores. Nutr Res Rev 13:107-138

Mayes RW, Lamb CS (1984) The possible use of $n$-alkanes in herbage as indigestible faecal markers. Proc Nutr Soc 43:39A 
Mayes RW, Lamb CS, Colgrove PM (1986) The use of dosed and herbage $n$-alkanes as markers for the determination of herbage intake. J Agric Sci Camb 107:161-170. doi:10. 1017/S0021859600066910

Mayes RW, Beresford NA, Lamb CS, Barnett CL, Howard BJ, Jones B-EV, Eriksson O, Hove K, Pedersen Ø, Staines BW (1994) Novel approaches to the estimation of intake and bioavailability of radiocaesium in ruminants grazing forested areas. Sci Total Environ 157:289-300. doi:10.1016/ 0048-9697(94)90592-4

Mole S, Butler LG, Iason G (1990) Defense against dietary tannin in herbivores - a survey for proline-rich salivary proteins in mammals. Biochem Syst Ecol 18:287-293. doi:10.1016/0305-1978(90)90073-O

Mysterud A, Pérez-Barbería FJ, Gordon IJ (2001) The effect of season, sex and feeding style on home range area versus body mass scaling in temperate ruminants. Oecologia 127:30-39. doi:10.1007/s004420000562

Naveh Z (1982) The dependence of the productivity of a semiarid mediterranean hill pasture ecosystem on climatic fluctuations. Agric Environ 7:47-61

Neyraud E, Sayd T, Morzel M, Dransfield E (2006) Proteomic analysis of human whole and parotid salivas following stimulation by different tastes. J Proteome Res 5: 2474-2480. doi:10.1021/pr060189z

Parker WJ, Morris ST, Garrick WJ, Vincent GL, McCutcheon SN (1990) Intraruminal chromium controlled release capsules for measuring herbage intake in ruminants-a review. Proc NZ Soc Anim Prod 50:437-442

Patamia M, Messana I, Ptruzzelli R, Vitali A, Inzitari R, Cabras T, Fanali C, Scarano E, Contucci A, Galtieri A, Castagnola M (2005) Two proline-rich peptides from pig (Sus scrofa) salivary glands generated by pre-secretory pathway underlying the action of a proteinase cleaving ProAla bonds. Peptides 26:1550-1559. doi:10.1016/j.peptides. 2005.02.021

Pérez-Barberia FJ, Gordon IJ (2001) Relationships between oral morphology and feeding style in the ungulata: a phylogenetically controlled evaluation. Proc R Soc Lond B 268:1023-1033. doi:10.1098/rspb.2001.1619

Pérez-Maldonado RA, Norton BW, Kerven GL (1995) Factors affecting in vitro formation of tannin protein complexes. J Sci Food Agric 69:291-298. doi:10.1002/jsfa.2740690305

Pérez-Ramos IM, Zavala MA, Maranon T, Díaz-Villa MD, Valladares F (2008) Dynamics of understory herbaceous plant diversity following shrub clearing of cork oak forests: a five-year study. For Ecol Manage 255:3242-3253

Pinto Correia T (1993) Threatened landscape in Alentejo, Portugal: the 'montado' and other 'agro-silvo-pastoral' systems. Landsc Urban Plan 24:43-48. doi:10.1016/01692046(93)90081-N

Plieninger T, Wilbrand C (2001) Land use, biodiversity conservation, and rural development in the Dehesas of Cuatro Lugares, Spain. Agrofor Syst 51:23-34. doi:10.1023/A: 1006462104555

Proctor GB, Carpenter GH (2007) Regulation of salivary gland function by autonomic nerves. Auton Neurosci 133:3-18. doi:10.1016/j.autneu.2006.10.006

Provenza FD, Cincotta RP (1993) Foraging as a self-organizational learning process: accepting adaptability at the expense of predictability. In: Hughes RN (ed) Diet selection: an interdisciplinary approach to foraging behaviour. Blackwell Scientific Publications, London, pp 78-101

Provenza FD, Malechek JC (1984) Diet selection by domestic goats in relation to blackbrush twig chemistry. J Appl Ecol 21:831-841

Robbins CT, Hanley TA, Hagerman AE, Hjeljord O, Baker DL, Schwartz CC, Mautz WW (1987) Role of tannins in defending plants against ruminants: reduction in protein availability. Ecology 68:98-107

Rodríguez-Estévez V, García A, Peña F, Gómez AG (2009) Foraging of Iberian fattening pigs grazing natural pasture in the Dehesa. Livest Sci 120:135-143. doi:10.1016/j. livsci.2008.05.006

Rogosic J, Estell RE, Skobic D, Martinovic A, Maric S (2006) Role of species diversity and secondary compound complementarity on diet selection of mediterranean shrubs by goats. J Chem Ecol 32:1279-1287. doi:10.1007/s10886006-9084-1

Sales-Baptista E (1995) A comparative study of trophic strategies in goats and sheep under restricted food intake. $\mathrm{PhD}$ dissertation, Universidade de Évora, Portugal (In portuguese)

Sales-Baptista E (2001) Effect of poliphenols on the use of shrub resources by ruminants. Contrato Praxis n ${ }^{\circ}$ /3.2/CA/1982/ 95, Estação Zootécnica Nacional, Instituto de Investigação Agrária, Santarém, Portugal (In portuguese)

Sales-Baptista E, Lamy E, Mau M, Capela e Silva F, Coelho AV (2009) Variation in salivary protein composition related to feeding behavior and its ecological implications. In: Zhang W, Liu H (eds) Behavioral and chemical ecology. Nova Science Publishers Inc., New York, pp 115-136

Salles C, Chagnon MC, Feron G, Guichard E, Laboure H, Morzel M, Semon E, Tarrega A, Yven C (2011) In-mouth mechanisms leading to flavor release and perception. Crit Rev Food Sci Nutr 51:67-90. doi:10.1080/10408390903044693

Salt CA, Mayes RW, Colgrove PM, Lamb CS (1994) The effects of season and diet composition on the radiocaesium intake by sheep grazing on heather moorland. J Appl Ecol 31:125-136

Scocco P, Sparvoli D, Catorci A (2006) Evaluation of the Italian Apennine ecosystems with respect to anatomical and ethological characteristics of the roe deer. In: Gafta D, Gafta D, Akeroyd J (eds) Nature conservation, concepts and practice. Springer, Berlin, pp 328-335. doi:10.1007/ 978-3-540-47229-2_32

Scocco P, Aralla M, Catorci A, Belardinelli C, Arrighi S (2011) Immunodetection of aquaporin 5 in sheep salivary glands related to pasture vegetative cycle. Folia Histochem $\mathrm{Cy}-$ tobiol 49:458-464. doi:10.5603/FHC 2011.0065

Seligman NG (1996) Management of Mediterranean grasslands. In: Hodgson J, Illius AW (eds) The ecology and management of grazing systems. CAB International, Wallingford, pp 359-392

Shimada T (2006) Salivary proteins as a defense against dietary tannins. J Chem Ecol 32:1149-1163. doi:10.1007/s10886006-9077-0

Specht RL, Rundel PW (1990) Sclerophylly and foliar nutrient status of Mediterranean-climate plant communities in Southern Australia. Aust J Bot 38:459-474. doi:10.1071/ BT9900459 
Spielmann N, Wong DT (2011) Saliva: diagnostics and therapeutic perspectives. Oral Dis 17:345-354. doi:10.1111/j. 1601-0825.2010.01773.x

Stolte M, Ito S (1996) A comparative ultrastructural study of the parotid gland acinar cells of nine wild ruminant species (mammalian, artiodactyla). Eur J Morphol 34:79-85

Vaithiyanathan S, Mishra JP, Sheikh Q, Kumar R (2001) Salivary glands tannins binding proteins of sheep and goat. Indian J Anim Sci 71:1131-1134

Vaz M, Maroco J, Ribeiro N, Gazarini LC, Pereira JS, Chaves MM (2010) Leaf-level responses to light in two co- occurring Quercus (Quercus ilex and Quercus suber): leaf structure, chemical composition and photosynthesis. Agrofor Syst 82:173-181. doi:10.1007/s10457-010-9343-6

Yisehak K, Becker A, Rothman JM, Dierenfeld ES, Marescau B, Bosch G, Hendriks W, Janssens GPJ (2012) Amino acid profile of salivary proteins and plasmatic trace mineral response to dietary condensed tannins in free-ranging zebu cattle (Bos indicus) as a marker of habitat degradation. Livest Sci 144:275-280. doi:10.1016/j.livsci.2011.12.020 